\title{
Exploratory study on sequestration of some essential metals by indigo carmine food dye
}

\author{
Thalita Boldrin Zanoni, Arnaldo Alves Cardoso, Maria Valnice Boldrin Zanoni, \\ Antonio Aparecido Pupim Ferreira*
}

Institute of Chemistry, State University of São Paulo “Júlio de Mesquita Filho”

\begin{abstract}
Indigo carmine forms a stable complex with different ions, and the stability constant of the complexes were evaluated as $\log \mathrm{K}$ equal to $5.75 ; 5.00 ; 4.89$ and 3.89 for complexes with $\mathrm{Cu}(\mathrm{II}), \mathrm{Ni}(\mathrm{II}), \mathrm{Co}(\mathrm{II})$ and $\mathrm{Zn}(\mathrm{II})$ ions, respectively, in $0.1 \mathrm{~mol} \mathrm{~L}^{-1}$ carbonate buffer solution at $\mathrm{pH} 10$. The interaction between $\mathrm{Cu}$ (II) ions and indigo carmine (IC) in alkaline medium resulted in the formation of the $\mathrm{Cu}_{2}$ (IC) complex, measured by the spectrophotometric method, with a stoichiometric ratio between indigo carmine and metal ions of 2:1 (metal-ligand). The reported method has also been successfully tested for determination of copper in pharmaceutical compounds based on copper-gluconate without pre-treatment.
\end{abstract}

Uniterms: Metal sequestration. Indigo carmine. Food dye/complexation. Spectrophotometric analysis. Copper/determination.

\begin{abstract}
Índigo carmim forma complexos estáveis com diferentes íons e a constante de estabilidade dos complexos foi avaliada como log $\mathrm{K}$ igual 5,75; 5,00; 4,89 e 3,89, respectivamente, para os complexos com os íons $\mathrm{Cu}(\mathrm{II}), \mathrm{Ni}(\mathrm{II}), \mathrm{Co}(\mathrm{II})$ e $\mathrm{Zn}(\mathrm{II})$ em solução tampão carbonato $0,1 \mathrm{~mol} \mathrm{~L}^{-1}, \mathrm{pH} 10$. A interação entre o íon $\mathrm{Cu}$ (II) e índigo carmin (IC) em meio alcalino resultou na formação do complexo $\mathrm{Cu}_{2}$ (IC) monitorado por método espectrofotométrico, com razão estequiométrica entre o índigo carmim e o íon metálico de 2:1 (metal-ligante). O método relatado também tem sido testado com sucesso para determinação de cobre em compostos farmacêuticos à base de cobre-gliconato sem qualquer pré-tratamento.
\end{abstract}

Unitermos: Sequestro de metal. Índigo carmim. Corante alimentar/complexação. Análise espectrofotométrica. Cobre/determinação.

\section{INTRODUCTION}

Copper, zinc, cobalt, iron and nickel play a vital role in human metabolism, since they are involved in almost all known important reactions and metabolic routes (Devlin, 2002). Therefore, the knowledge of their interactions with a food dye can be very important since they can appropriate important metallic compounds to the human organism. As one of the most important essential transition metals, copper is involved in a variety of biological processes such as embryo development, connective tissue formation, temperature control and nerve cell function (Wang, Guo, 2006). Copper is transported from dietary intake

"Correspondence: A. A. Pupim Ferreira. Laboratório de Eletroanalítica, Departamento de Química Analítica, Instituto de Química - Universidade Estadual Paulista (UNESP). Rua Prof. Francisco Degni s/n - 14800-900 - Araraquara - SP, Brasil. E-mail: antoferr@iq.unesp.br through the serum and into the organism via a variety of transporters and patients with deficiency of this metal need to be treated with copper supplements. Menkes disease is characterized by a systemic copper deficiency resulting from a recessive mutation in copper transporter. However, it is known that copper can cause toxic effects at elevated concentrations (White, Rainbow, 1985), whose toxicity depends on environmental factors such as $\mathrm{pH}$, salinity, biological media and organic matter (Campbell, 1995; Allen, Hansen, 1996). Taking into consideration that treatment of both diseases involves copper chelation therapy, the study of new complexing agents of copper with low toxicity seems relevant.

The analysis of copper has gained extensive attention. Generally, absorption spectrometry (Pohl, Sergiel, 2010; Alizadeh et al., 2010), ICP-OES ( He et al., 2010), ICP-MS (Yang et al., 2010, Matush et al., 2010), spectro- 
photometry (Sabel, Neureuther, Siemann, 2010; Shah, Parmar, 2010), and electrochemical techniques (Manteanu, Dempsey, Maccormac, 2010; Heli et al., 2010) have been used for copper analyze in different matrices.

It is well known that most types of dyes form complexes with metal ions in aqueous media (Zollinger, 1991). Interactions between food dyes and metal ions may change their stability, toxicity and other physico-chemical properties of both metal and the dye. The toxicological evidence for synthetic colorants has led to reviewed safety of several compounds in most countries (Marmion, 1991). Accordingly, it is important for human health to know these complexes.

In addition, although many other methods have been used for dye analysis in food (Pearson, 1976; Nevado, Cabanillas, Salcedo, 1995; Blanco, Campaña, Barrero, 1996; Vidotti, Rollemberg, 2006; Mitic, Micic, Simonovic, 2009; Sharma, Singh, 2009; Gennaro, Abrigo, Cipolla, 1994; Suzuki et al., 1994; Fogg, Barros, Cabral, 1986; Barros, 1987; Barros, Cabral, Fogg, 1988; Dominguez, Diego, Mendez, 1990; Mo et al., 1992; Ni, Bai, 1997; Ni, Bai, Jin, 1997), no literature data on indigo carmine-metal complexes with copper have been found with this focus.

The present paper investigated the feasible complexation between indigo carmine (Figure 1) and some essential metals including $\mathrm{Cu}(\mathrm{II}), \mathrm{Ni}(\mathrm{II}), \mathrm{Zn}(\mathrm{II}), \mathrm{Co}(\mathrm{II}), \mathrm{Fe}(\mathrm{II})$, $\mathrm{Fe}(\mathrm{III})$ and $\mathrm{K}(\mathrm{I})$ by the spectrophotometric method. The possibility of accomplishing the determination of copper (II) via a complexation reaction with indigo carmine, and its application in pharmaceutical formulations of copper complex containing $\mathrm{Cu}$ (II)-gluconate, is also discussed.

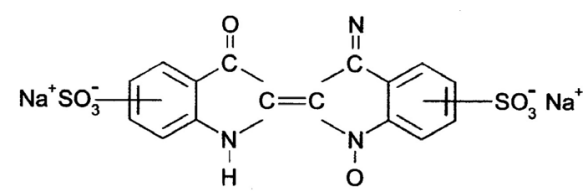

FIGURE 1 - Chemical structure of indigo carmine dye.

\section{MATERIAL AND METHODS}

\section{Apparatus and procedures}

Analytical grade reagents supplied by Merck and using high purity water from a Milli-Q system (Millipore Inc., USA) were used in the preparation of all solutions. Spectrophotometric analysis employed $0.1 \mathrm{~mol} \mathrm{~L}^{-1}$ carbonate buffer solution at $\mathrm{pH} 10,0.1 \mathrm{~mol} \mathrm{~L}^{-1}$ phosphate buffer solution at $\mathrm{pH} 6.0$ and $8.0,0.1 \mathrm{~mol} \mathrm{~L}^{-1}$ sodium hydroxide solution and $0.1 \mathrm{~mol} \mathrm{~L}^{-1}$ acetate buffer solution. Indigo carmine (Aldrich Company Inc.) and copper stock so- lutions $\left(1 \times 10^{-2} \mathrm{~mol} \mathrm{~L}^{-1}\right)$ were prepared from the dry pure substances in water.

Measurements of $\mathrm{pH}$ were made using a Micronal pH meter B222 model with a Micronal combined $\mathrm{pH}$ reference electrode. Except when stated otherwise, all the experiments were done at room temperature $\left(25^{\circ} \mathrm{C}\right)$. Experiments involving controlled temperature were carried out in an ultra-thermostatic bath (Nova Técnica, Brazil).

Spectrophotometric measurements were performed on a Hewlett Packard 8453 spectrophotometer operating from $190-1000 \mathrm{~nm}$ using a quartz cell of $1 \mathrm{~mL}$ with an optical path of $1 \mathrm{~cm}$. Different volumes of indigo carmine stock solution were transferred to a volumetric flask of $10 \mathrm{~mL}$ containing an appropriate buffer solution to which copper or cooper-gluconate solution was added, and aliquot of the final solution was placed in the spectrophotometric cell.

\section{RESULTS AND DISCUSSION}

\section{Spectrophotometric behavior of $\mathrm{Cu}(\mathrm{II}) /$ indigo carmine}

The interaction between indigo carmine and $\mathrm{Cu}(\mathrm{II})$ ions was followed in the $\mathrm{pH}$ range 2-12, by monitoring changes in the absorption spectrum over the range from 800 to $190 \mathrm{~nm}$. The optimal conditions of the formation of the complex ions were also evaluated.

Figure 2 shows the absorption spectra (in Absorbance, A) for $1 \times 10^{-5} \mathrm{~mol} \mathrm{~L}^{-1}$ of indigo carmine (A) in aqueous solution, for $1 \times 10^{-3} \mathrm{~mol} \mathrm{~L}^{-1} \mathrm{Cu}$ (II) in aqueous solution and also for mixture of both in aqueous solutions $(\mathrm{C})$. The absorption band of indigo carmine (Figure 2A) shows a maximum absorption at 615,320 and $270 \mathrm{~nm}$, attributed to the indigoide group present as chromophore center (Gordon et al., 1983). Selecting $615 \mathrm{~nm}$ as the measuring wavelength a linear relationship was obtained from $1 \times 10^{-5}$ to $1 \times 10^{-4} \mathrm{~mol} \mathrm{~L}^{-1}$, using the equation: $\mathrm{A}=0.00901+0.202 \times 10^{5} \mathrm{C}\left(\mathrm{C}=\mathrm{mol} \mathrm{L}^{-1}\right)$, $\mathrm{r}=0.9997$. Copper (II) exhibits two characteristic bands at $300 \mathrm{~nm}$ and $807 \mathrm{~nm}$ only for concentrations increasing from $1 \times 10^{-3}$ to $7.5 \times 10^{-2} \mathrm{~mol} \mathrm{~L}^{-1}$ (Figure 3B). The band at $300 \mathrm{~nm}$ increased linearly with concentration of $\mathrm{Cu}$ (II) in agreement with the equation: $\mathrm{A}=-0.00207+15.52 \mathrm{C}\left(\mathrm{C}=\mathrm{mol} \mathrm{L}^{-1}\right)$, $\mathrm{r}=0.9923$. In the UV-Vis spectrum (Figure $3 \mathrm{C}$ ) obtained for the product of the reaction between indigo carmine and $\mathrm{Cu}(\mathrm{II})$ ion, both in aqueous solutions, shows a broad absorption band with maximum absorbance at $715 \mathrm{~nm}$ that appears concomitantly with significant decreases in the absorption band of the indigo carmine $(615 \mathrm{~nm})$. As $\mathrm{Cu}(\mathrm{II})$ or indigo carmine does not absorb in this range of wavelengths, this behavior is indicative that there is formation of a complex between indigo carmine and $\mathrm{Cu}(\mathrm{II})$. 


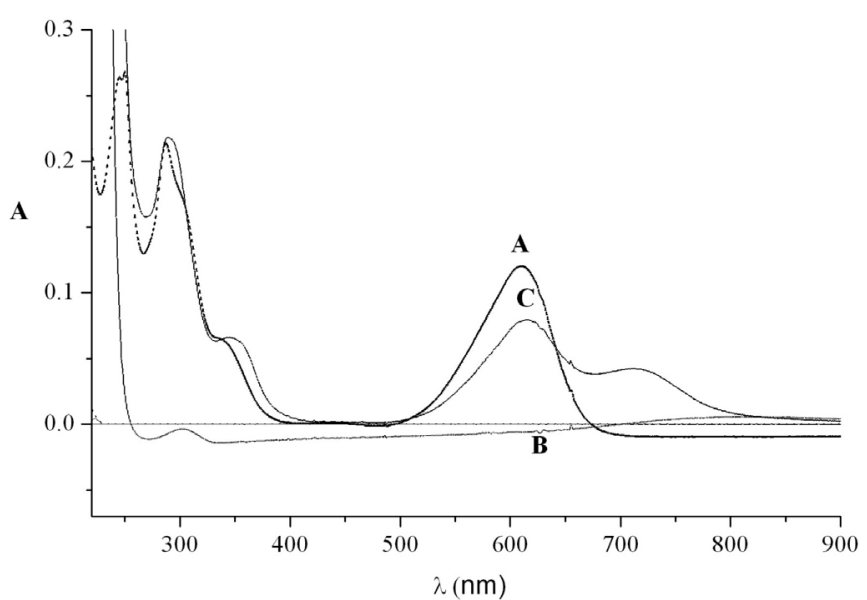

FIGURE 2 - UV-Vis spectra recorded for $1 \times 10^{-5} \mathrm{~mol} \mathrm{~L}^{-1}$ of indigo carmine in aqueous solution (A), for $1 \times 10^{-3} \mathrm{~mol} \mathrm{~L}^{-1}$ aqueous solution of $\mathrm{Cu}(\mathrm{II})(\mathbf{B})$ and after $10 \mathrm{~min}$ of mixture of both in aqueous medium $(\mathbf{C})$.

\section{Optimum conditions for complex formation}

The influence of $\mathrm{pH}$ on the formation of yielding complex was followed by recording the UV-Vis spectrum of the reaction mixture between $1 \times 10^{-5} \mathrm{~mol} \mathrm{~L}^{-1} \mathrm{IC}$ and $1 \times 10^{-4} \mathrm{~mol} \mathrm{~L}^{-1} \mathrm{Cu}(\mathrm{II})$ solutions at $0.1 \mathrm{~mol} \mathrm{~L}^{-1}$ acetate buffer solution, $\mathrm{pH} 2.0$ and 4.0; $0.1 \mathrm{~mol} \mathrm{~L}^{-1}$ phosphate buffer solution, pH 6.0 and $8.0 ; 0.1 \mathrm{~mol} \mathrm{~L}^{-1}$ carbonate buffer solution $\mathrm{pH} 10$ and $0.1 \mathrm{~mol} \mathrm{~L}^{-1}$ sodium hydroxide solution at $\mathrm{pH} 12$. The increased intensity of the absorption band at $715 \mathrm{~nm}$ (IC-copper II) and decrease at $615 \mathrm{~nm}$ (IC) at different $\mathrm{pH}$ values was followed by measuring of the absorbance, which was shown in Figure 3.

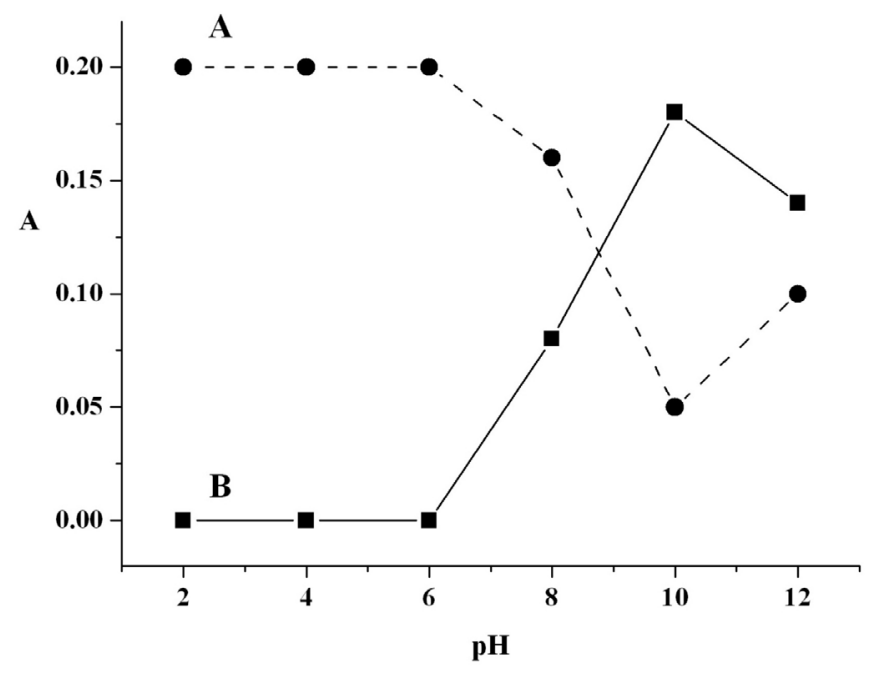

FIGURE 3 - Plots of absorbance $v s \mathrm{pH}$ of the indigo carmine solution $\left(1 \times 10^{-5} \mathrm{~mol} \mathrm{~L}^{-1}\right)$ at $615 \mathrm{~nm}(\mathbf{A})$ and complex $(\mathrm{Cu}(\mathrm{II})=$ $\left.1 \times 10^{-4} \mathrm{~mol} \mathrm{~L}^{-1}\right)$ generated at $715 \mathrm{~nm}(\mathbf{B})$.
Indigo carmine showed no change in UV spectrum during $180 \mathrm{~min}$ of analysis at $\mathrm{pH} 2-12$. But in the presence of $\mathrm{Cu}(\mathrm{II})$ and $\mathrm{pH} \geq 8$ a marked decrease in the absorbance at $615 \mathrm{~nm}$ was seen, concomitant to the increase of absorption band at $715 \mathrm{~nm}$. Under this condition, $\mathrm{Cu}(\mathrm{OH})_{2}$ will start to precipitate in aqueous solution under alkaline conditions, but this did not occur in the presence of indigo carmine. This fact confirms the existence of soluble complex ions between $\mathrm{Cu}(\mathrm{II})$ and indigo carmine under alkaline conditions.

The stability of the resulting complex formed under alkaline conditions was investigated by testing a mixture solution of indigo carmine and $\mathrm{Cu}$ (II) in equimolar concentrations of $1 \times 10^{-4} \mathrm{~mol} \mathrm{~L}^{-1}$ at $0.1 \mathrm{~mol} \mathrm{~L}^{-1}$ carbonate buffer solution at $\mathrm{pH} 10$, whose recording spectra were recorded every $10 \mathrm{~min}$. The results are shown in Figure 4. The complex reached maximum absorption after $5 \mathrm{~min}$ of preparing the reaction solution and remained stable for 3 hours at $25^{\circ} \mathrm{C}$. The absorbance of indigo carmine at $615 \mathrm{~nm}$ also decreased in function of time and reached maximum decrease after $20 \mathrm{~min}$.

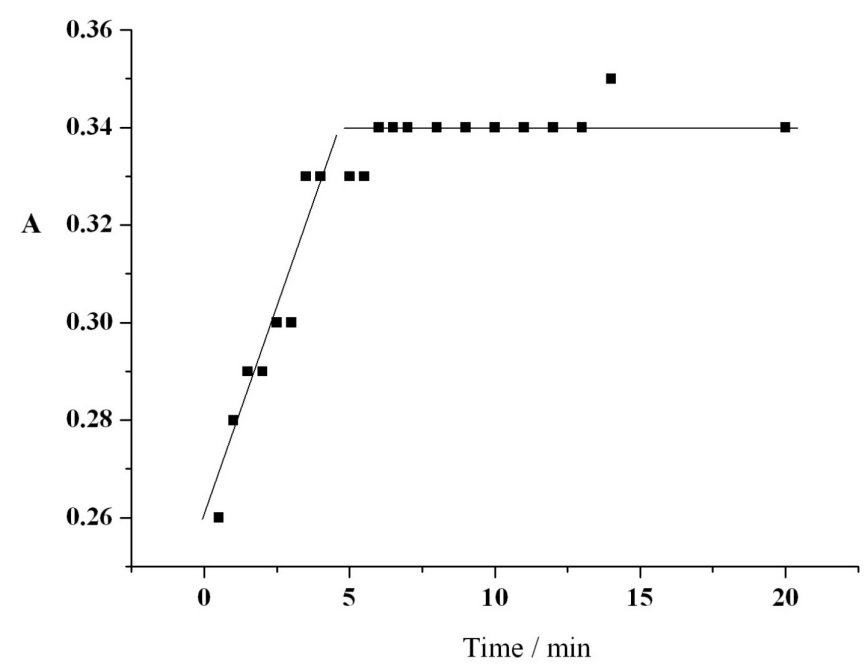

FIGURE 4 - Influence of time on absorbance of complex ions measured at $715 \mathrm{~nm}$. Indigo carmine solution $=1 \times 10^{-4} \mathrm{~mol} \mathrm{~L}^{-1}$ and $1 \times 10^{-4} \mathrm{~mol} \mathrm{~L}^{-1} \mathrm{Cu}(\mathrm{II})$ solution in $0.1 \mathrm{~mol} \mathrm{~L}^{-1}$ carbonate buffer solution at $\mathrm{pH} 10$.

The influence of temperature on the formed complex was investigated by keeping the mixture of $1 \times 10^{-4} \mathrm{~mol} \mathrm{~L}^{-1}$ IC and $\mathrm{Cu}$ (II) solutions for a controlled period of $10 \mathrm{~min}$ under controlled temperatures of $25,35,45$ and $55^{\circ} \mathrm{C}$. The solution was then cooled and the absorbance measured at $715 \mathrm{~nm}$. The results indicated that the complex did not exhibit significant changes up to $35^{\circ} \mathrm{C}$, but absorbance is $58 \%$ lower after $10 \mathrm{~min}$ under $55^{\circ} \mathrm{C}$, indicating that there is a great influence by temperature, probably through shifting the equilibrium toward formation of the hydroxy complex. 
The metal-to-ligand ratio in the complex was determined by spectrophotometric measurements of the solutions having $1 \times 10^{-4} \mathrm{~mol} \mathrm{~L}^{-1}$ indigo carmine and different initial metal concentrations from $1 \times 10^{-5}$ to $1 \times 10^{-4} \mathrm{~mol} \mathrm{~L}^{-1}$ $\mathrm{Cu}$ (II) solutions, with the respective plot depicted in Figure 5. The results indicated the formation of a complex with a 2:1 metal-to-ligand ratio, which suggests the formation of complex species $(\mathrm{Cu})_{2} \mathrm{IC}$. Using the stoichiometric ratio, the stability constant was determined by the molar ratios method (Bulatov, 1986) at $\mathrm{pH} 10$. The values of $\log \mathrm{K}=5.75$ indicated that a stable complex was formed between $\mathrm{Cu}(\mathrm{II})$ and IC.

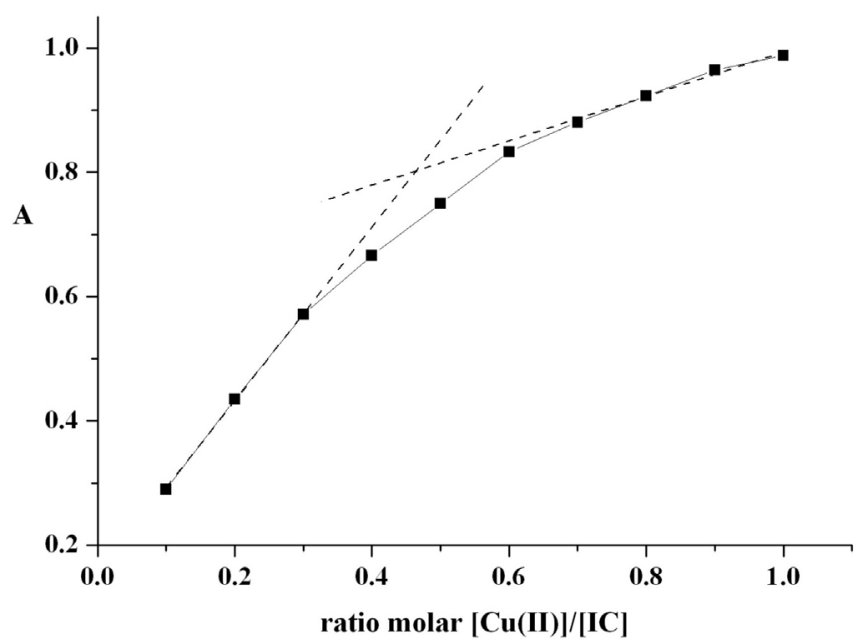

FIGURE 5 - Plots of absorbance of complex versus molar ratio of components: $1 \times 10^{-4} \mathrm{~mol} \mathrm{~L}^{-1}$ indigo carmine and $1 \times 10^{-6}$ to $1 \times 10^{-4} \mathrm{~mol} \mathrm{~L}^{-1} \mathrm{Cu}(\mathrm{II})$ solutions.

The significant influence of the sequence of the added reagents on complex formation was observed during spectrophotometric measurements. A qualitative difference in complexation was evident when the sample containing ligand concentration in buffer solution at $\mathrm{pH}$ 10 received the copper solution, indicating that hydroxy complex are avoided and that the complex metal-indigo carmine is preponderant.

\section{Beer's Law and sensitivity}

A calibration graph for the determination of copper was prepared under optimum experimental conditions (0.1 mol L-1 carbonate buffer solution, $\mathrm{pH} 10$, indigo carmine concentration of $1.0 \times 10^{-4} \mathrm{~mol} \mathrm{~L}^{-1}$, reaction time $=20 \mathrm{~min}$ and temperature $=25^{\circ} \mathrm{C}$ ). The respective spectra obtained for $\mathrm{Cu}(\mathrm{II})$ concentrations ranging from $1 \times 10^{-5}$ to $1 \times 10^{-4} \mathrm{~mol} \mathrm{~L}^{-1}$ is shown in Figure 6.

The absorbance of indigo carmine decreased in function of $\mathrm{Cu}(\mathrm{II})$ addition, concomitant to an increase of

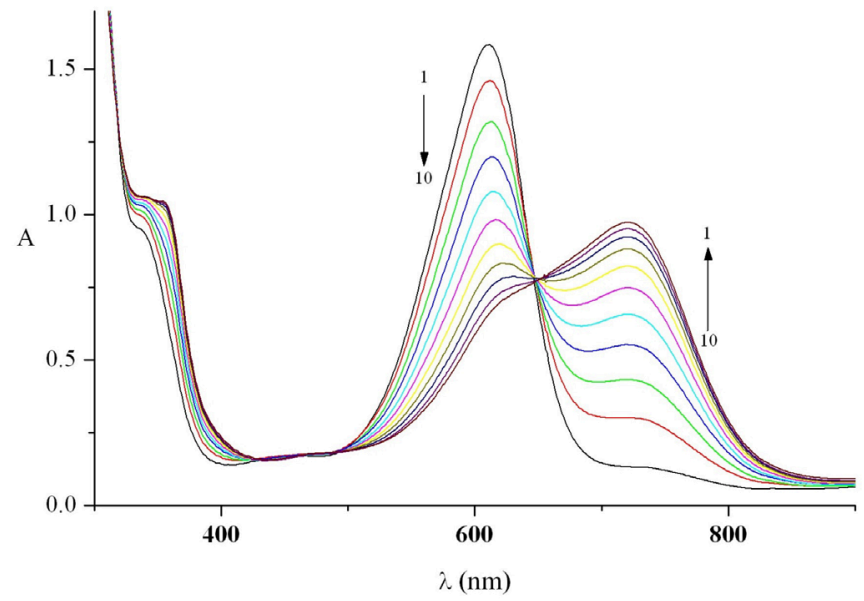

FIGURE 6 - UV-Vis spectra obtained for $1.0 \times 10^{-4} \mathrm{~mol} \mathrm{~L}^{-1}$ indigo carmine in $0.1 \mathrm{~mol} \mathrm{~L}^{-1}$ carbonate buffer solution at $\mathrm{pH} 10$ in the presence of $\mathrm{Cu}(\mathrm{II})$ solutions: 1)1.0; 2)2.0 3)3.0; 4)4.0; 5)5.0;

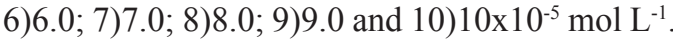

an extra peak at $715 \mathrm{~nm}$ attributed to the $\mathrm{Cu}(\mathrm{II})$ complex, showing an isobestic point at $650 \mathrm{~nm}$. Beer's law is obeyed within a range of $1 \times 10^{-5}$ to $5 \times 10^{-5} \mathrm{~mol} \mathrm{~L}^{-1}$ of copper measuring absorbance at $715 \mathrm{~nm}$, as shown in the graphs of Figure 7. The peak of indigo carmine also decreased linearly up to $5 \times 10^{-5} \mathrm{~mol} \mathrm{~L}^{-1}$, and reached a plateau at higher values of $\mathrm{Cu}$ (II). A wide linear relationship is obtained for lower concentrations of indigo carmine. For an indigo carmine concentration of $1 \times 10^{-5} \mathrm{~mol} \mathrm{~L}^{-1}$ in $0.1 \mathrm{~mol} \mathrm{~L}^{-1}$ carbonate buffer solution at $\mathrm{pH} 10$ it is possible to produce a calibration graph represented by the following linear regression equation: $\mathrm{A}=0.00103+1.15 \times 10^{3} \mathrm{C}\left(\mathrm{C}=\mathrm{mol} \mathrm{L}^{-1}\right), \mathrm{r}=0.9991$, $\mathrm{n}=9$. The molar absorptivity is $1.17 \times 104 \mathrm{~mol} \mathrm{~L}^{-1} \mathrm{~cm}^{-1}$. The detection limit obtained by measurement at $715 \mathrm{~nm}$ (three times the standard deviation of the intercept/slope) is

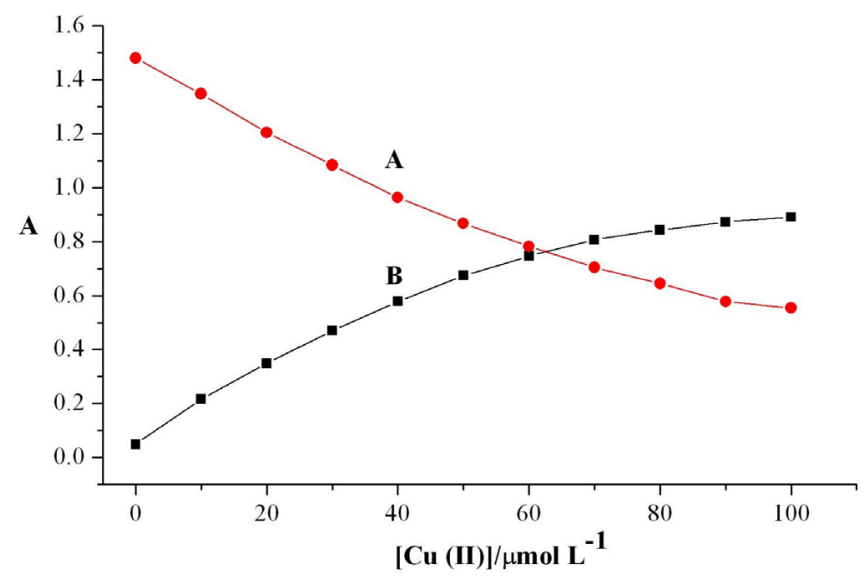

FIGURE 7 - Effect of $\mathrm{Cu}(\mathrm{II})$ on the absorbance of maximum absorbance of (A) $1 \times 10^{-4} \mathrm{~mol} \mathrm{~L}^{-1}$ indigo carmine solution in $0.1 \mathrm{~mol} \mathrm{~L}^{-1}$ carbonate buffer solution at $\mathrm{pH} 10(\lambda=615 \mathrm{~nm})$ and (B) the complex at $715 \mathrm{~nm}$. 
$4.28 \times 10^{-7} \mathrm{~mol} \mathrm{~L}^{-1}$. The precision of the method was checked by testing five replicate measurements using solution containing $1 \times 10^{-4} \mathrm{~mol} \mathrm{~L}^{-1}$ of indigo carmine and $1 \times 10^{-5} \mathrm{~mol} \mathrm{~L}^{-1}$ $\mathrm{Cu}$ (II) solution. The relative standard deviation is $1.3 \%$.

\section{Spectrophotometric behavior of other essential metals and indigo carmine}

Taking into consideration that indigo carmine can complex $\mathrm{Cu}(\mathrm{II})$ and form a stable product in alkaline medium, the proposed methodology was also tested in the sequestering action of indigo carmine in relation to essential metals including: $\mathrm{Zn}(\mathrm{II}), \mathrm{Ca}(\mathrm{II}), \mathrm{K}(\mathrm{I}), \mathrm{Co}(\mathrm{II})$, $\mathrm{Ni}(\mathrm{II}), \mathrm{Fe}(\mathrm{III}), \mathrm{Fe}(\mathrm{II}), \mathrm{Pb}(\mathrm{II}), \mathrm{Cd}(\mathrm{II})$. All these cations are highly relevant to metabolic equilibrium in human beings as essential micronutrients or due to toxicity effect.

To study the effect of various cations on the reaction with indigo carmine, a mixture of $1 \times 10^{-4} \mathrm{~mol} \mathrm{~L}^{-1}$ indigo carmine with $0.1 \mathrm{~mol} \mathrm{~L}^{-1}$ carbonate buffer solution at $\mathrm{pH} 10$ and variable concentration of metals from $1 \times 10^{-5}$ to $1 \times 10^{-3}$ mol L-1 were examined. The respective spectra obtained for Ni(II) is shown in Figure 8. The spectrophotometric behavior was very similar to that obtained for $\mathrm{Cu}(\mathrm{II})$, except for a maximum absorbance of the complex which occurs at $760 \mathrm{~nm}$. The absorbance at $760 \mathrm{~nm}$ increases with $\mathrm{Ni}(\mathrm{II})$, but a linear relationship is observed only from $1.0 \times 10^{-5}$ to $4.0 \times 10^{-5} \mathrm{~mol} \mathrm{~L}^{-1}$. The linear relationship is represented by the equation:

$$
\mathrm{A}=0.112+1022 \mathrm{C}\left(\mathrm{C}=\mathrm{mol} \mathrm{L}^{-1}\right), \mathrm{r}=0.9994, \mathrm{n}=7 .
$$

At higher concentrations of $\mathrm{Ni}$ (II) a deviation from linearity is observed indicating saturation of the complexing reaction. UV-Vis spectra obtained for Co(II) in the presence of indigo carmine in $0.1 \mathrm{~mol} \mathrm{~L}^{-1}$ carbonate buffer at $\mathrm{pH} 10$ also exhibits the same morphology, marked by the rising absorbance peak at $730 \mathrm{~nm}$. This peak has a lower intensity compared to $\mathrm{Cu}$ (II) or $\mathrm{Ni}(\mathrm{II})$, but also increases linearly with $\mathrm{Co}$ (II) concentration from $5 \times 10^{-5} \mathrm{~mol} \mathrm{~L}^{-1}$ up to $6 \times 10^{-4} \mathrm{~mol} \mathrm{~L}^{-1}$, following the equation: $\mathrm{A}=0.0409+$ 1064.8 C $\left(\mathrm{C}=\mathrm{mol} \mathrm{l}^{-1}\right), \mathrm{r}=0.9777, \mathrm{n}=7$.

The effect of the $\mathrm{Zn}(\mathrm{II})$ ions on the complex formation is less accentuated than for all metals described previously, but it is also possible to see the extra band at $713 \mathrm{~nm}$ at concentration of $\mathrm{Zn}$ (II) higher than $7.0 \times 10^{-5}$ mol L-1 using an indigo carmine concentration of $1 \times 10^{-4}$ $\mathrm{mol} \mathrm{L}^{-1}$. The absorbance increased linearly from $7 \times 10^{-5}$ to $7 \times 10^{-4} \mathrm{~mol} \mathrm{~L}^{-1}$ following the equation: $\mathrm{A}=0.0589+112.8$ $\mathrm{C}\left(\mathrm{C}=\mathrm{mol} \mathrm{L}^{-1}\right), \mathrm{r}=0.998, \mathrm{n}=5$.

Nevertheless, addition of $\mathrm{Pb}(\mathrm{II}), \mathrm{K}(\mathrm{I}), \mathrm{Cd}(\mathrm{II})$, $\mathrm{Fe}(\mathrm{III}), \mathrm{Fe}(\mathrm{II})$ and $\mathrm{Ca}(\mathrm{II})$ ions do not promote any alte- ration in the original spectra recorded for $1 \times 10^{-4} \mathrm{~mol} \mathrm{~L}^{-1}$ of indigo carmine, suggesting that there is no interaction between the food dye and these metallic compounds.

The metal-to-ligand ratio in the complexation of IC with $\mathrm{Ni}(\mathrm{II}), \mathrm{Co}(\mathrm{II})$ and $\mathrm{Zn}$ (II) ions determined by spectrophotometric measurements of the solutions containing $1 \times 10^{-4} \mathrm{~mol} \mathrm{~L}^{-1}$ indigo carmine and different initial metal concentrations, presented the typical formation of a complex with a 2:1 metal-to-ligand ratio as verified for $\mathrm{Cu}(\mathrm{II})$. In addition, the stability constant determined by the molar ratio method, presented values of $\log K$ ranging from 5.00, 4.89 and 3.89 for $\mathrm{Ni}(\mathrm{II}), \mathrm{Co}(\mathrm{II})$ and $\mathrm{Zn}(\mathrm{II})$, respectively. These results indicated that stable complexes are formed with food dye.

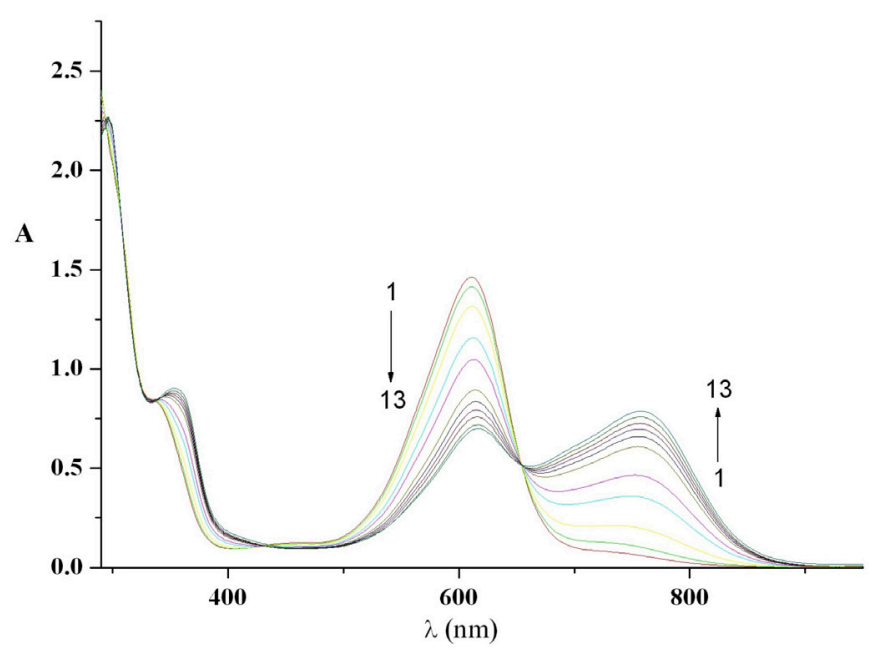

FIGURE 8 - UV-Vis spectra obtained for $1.0 \times 10^{-4} \mathrm{~mol} \mathrm{~L}^{-1}$ indigo carmine in $0.1 \mathrm{~mol} \mathrm{~L}^{-1}$ carbonate buffer solution at $\mathrm{pH} 10$ in the presence of $\mathrm{Ni}(\mathrm{II})$ solutions: 1) 1.0 ; 2) 2.0; 3) 3.0;4) 4.0; 5) 5.0 ; 6) 6.0 ; 7) 7.0; 8) 8.0;9) 9.0;10) 10;11) 20;12) 40 and 13) $80 \times 10^{-5} \mathrm{~mol} \mathrm{~L}^{-1}$.

\section{Copper determination in pharmaceutical formulations}

In order to investigate the interference of indigo carmine on copper source administered as a pharmaceutical formulation, its influence was tested in the available complex sample commercialized as cooper-gluconate. The solution is administered to treat symptoms of copper deficiency such as: hypercolesterolemy, anemia, leucopeny, bones demineralization, blood vessel fragility and other nutrition problems.

Samples of $20 \mu \mathrm{L}$ of Oligosol removed from a flask labeled as containing $0.725 \mathrm{mg} / 2 \mathrm{~mL}$ of copper complex were added to $10 \mathrm{ml}$ of a solution containing $1 \times 10^{-4} \mathrm{~mol} \mathrm{~L}^{-1}$ of indigo carmine in $0.1 \mathrm{~mol} \mathrm{~L}^{-1}$ carbonate buffer solution at $\mathrm{pH} 10$. The spectra obtained exhibited the peak at 
$715 \mathrm{~nm}$, clearly indicating that indigo carmine can displace copper from the oligasol complex.

In order to test the analytical application of this method, the matrix effect was evaluated by additionrecovery experiments carried out using the commercial pharmaceutical formulation. The results obtained by the standard addition method indicated a mean of recoveries ranging from 94.8 to $102.3 \%$ of copper using the proposed procedure for testing a triplicate sample.

The proposed procedure was confirmed by spectrophotometric measurement of Oligosol which presented maximum absorbance at $283 \mathrm{~nm}$. The copper content was determined by the standard addition method and compared with the proposed method using indigo carmine. The content of copper calculated by both methods is in agreement, as well as the label values described by the industrial laboratory. The results obtained were also compared by applying the $\mathrm{F}$ - test and $\mathrm{t}$ - test at $95 \%$ confidence level (Miller et al., 1993). In both cases the calculated $\mathrm{F}$ or $\mathrm{t}$ values did not exceed the theoretical values $\left(\mathrm{F}_{3.3}=9.28\right.$; $\mathrm{t}_{6}=2.45$ ), confirming that there are no significant differences between the results obtained by the two procedures.

\section{CONCLUSIONS}

The interaction between $\mathrm{Cu}(\mathrm{II})$ ions and indigo carmine in an alkaline medium resulted in the formation of $\mathrm{Cu}_{2}$ (IC) complex. Spectrophotometric methods were used to reveal that the stoichiometric ratio between indigo carmine and copper is $2: 1$. The molar absorptivity was $1.17 \times 10^{4} \mathrm{~mol} \mathrm{~L}^{-1} \mathrm{~cm}^{-1}$ at $715 \mathrm{~nm}$ and the stability constant of the complex $\log \mathrm{K}=5.75$, calculated at $\mathrm{pH} 10$, were obtained by spectrophotometric data. Complex of indigo carmine with $\mathrm{Ni}(\mathrm{II}), \mathrm{Co}(\mathrm{II})$ and $\mathrm{Zn}$ (II) ions in $0.1 \mathrm{~mol} \mathrm{~L}^{-1}$ carbonate buffer solution at $\mathrm{pH} 10$ are also formed, which is potential interference reaction in the method. The reported method has been successfully tested for determination of copper in pharmaceutical compounds based on copper-gluconate without expected interferences caused by excipients.

\section{ACKNOWLEDGMENTS}

We would like to thank the FAPESP, CNPq and CAPES for the financial support.

\section{REFERENCES}

ALIZADEH, K.; ZOHREVAND, S.; GHIASVAND, A.R.; HASHEMI, P.; SHAMSIPUR, M.; SHARGHI, H.; KHALIFEH, R. Selective homogeneous liquid-liquid extraction and preconcentration of copper (II) into a micro droplet using a benzo-substituted macrocyclic diamide, and its determination by electrothermal atomic absorption spectrometry. Microchim. Acta, v.168, p.115-121, 2010.

ALLEN, H.E.; HANSEN, D.J. The importance of trace metal speciation to water quality criteria. Water Environ. Res., v.68, p.42-54, 1996.

BARROS, A.A. Differential pulse polarographic determination of synthetic colouring matters in drugs and cosmetics. Analyst, v.112, p.1359-1364, 1987.

BARROS, A.A.; CABRAL, J.O.; FOGG, A.G. Use of gelatin in the differential pulse polarographic determination and identification of synthetic colouring matters in drugs and cosmetics. Analyst, v.113, p.853-858, 1988.

BLANCO, C.C.; CAMPAÑA, A.M.G.; BARRERO, F.A. Derivative spectrophotometric resolution of mixtures of the food colourants Tartrazine, amaranth and Curcumin in a micellar medium. Talanta, v.43, p.1019-1027, 1996.

BULATOV, M.I.; KALINKIN, I.P. Practical manual of photometric analyses. 5.ed. Leningrad: Khimiya, 1986. p.241-244.

CAMPBELL, P.G.C., Interactions between trace metals and aquatic organisms, a critique of the free-ion activity model. In: TESSIER, A.; TURNER, D.R. (Eds.). Metal speciation and bioavailability in aquatic systems. IUPAC Series on analytical and physical chemistry of environmental systems. Berlin: Springer, 1995. p.45-102.

DEVLIN, T. M. Textbook of biochemistry with clinical correlations. 5.ed. New York: John Wiley \& Sons, Inc., 2002. $1216 \mathrm{p}$.

DOMINGUEZ, F.B.; DIEGO, F.G.; MENDEZ, J.H. Determination of sunset yellow and tartrazine by differential pulse polarography. Talanta, v.37, p.655-658, 1990.

FOGG, A.G.; BARROS, A.A.; CABRAL, J.O. Differential pulse adsorptive stripping voltammetry of food and cosmetic synthetic colouring matters and their determination and partial identification in tablet coatings and cosmetics. Analyst, v.111, p.831-835, 1986.

GENNARO, M.C.; ABRIGO, C.; CIPOLLA, G. Highperformance liquid chromatography of food colours and its relevance in forensic chemistry. J. Chromatogr. A, v.674, p.281-299, 1994. 
GORDON, P.F.; GREGORY, P. Organic chemistry in colour. New York: Springer-Velag, 1983. 211 p.

HE, Q.; HU, Z.; JIANG, Y.; CHANG, X.; TU, Z.; ZHANG, L. Preconcentration of $\mathrm{Cu}(\mathrm{II}), \mathrm{Fe}$ (II) and $\mathrm{Pb}(\mathrm{II})$ with 2-((2-aminoethylamino)methyl)phenol-functionalized activated carbon followed by ICP-OES determination. $J$. Hazard. Mater., v.175, p.710-714, 2010.

HELI, H.; ZARGHAN, M.; JABBARI, A.; PARSAEI, A.; MOOSAVI-MOVAHEDI, A. A. Electrocatalytic oxidation of the antiviral drug acyclovir on a copper nanoparticlesmodified carbon paste electrode. J. Solid State Electrochem., v.14, p.787-795, 2010.

MARMION, D.M. Handbook of U.S. colorants: foods, drugs and cosmetics and medical devices. 3.ed. New York: John Wiley \& Sons, 1991. 575 p.

MATUSCH, A.; DEPBOYLU, C.; PALM, C.; WU, B.; HOGLINGER, G. U.; SCHAFER, M. K-H.; BECKER, J. $\mathrm{S}$. Cerebral bioimaging of $\mathrm{Cu}, \mathrm{Fe}, \mathrm{Zn}$ and $\mathrm{Mn}$ in the MPTP mouse model of Parkinson's disease using laser ablation inductively coupled plasma mass spectrometry (LA-ICPMS). J. Am. Soc. Mass Spectrom., v.21, p.161-171, 2010.

MILLER, J.C.; MILLER, J.N. Statistics for analytical chemistry. 3.ed. West Sussex: Ellis Horwood PRT Prentice Hall, 1993. 202 p.

MITIC, S.S.; MICIC, R.J.; SIMONOVIC, R.M. Analytical application of food dye Sunset Yellow for the rapid kinetic determination of traces of copper(II) by spectrophotometry. Food Chem., v.117, p.461-465, 2009.

MO, S.; NA J.; MO, H.; CHEN, L. Voltammetric determination of indigo carmine and amaranth on a silver-based mercury film electrode. Anal. Lett., v.25, p.899-909, 1992.

MUNTEANU, G.; DEMPSEY, E.; MACCORMAC, T. Ultrafast voltammetric determination of biological thiols on the copper nanodoped mercury monolayer carbon fiber electrode, J. Electroanal. Chem., v.638, p.109-118, 2010.

NEVADO, J.J.B.; CABANILLAS, C.G.; SALCEDO, A.M.C. Simultaneous spectrophotometric determination of three food dyes by using the first derivative of ratio spectra. Talanta, v.42, p.2043-2051, 1995.
NI, Y.; BAI, J. Simultaneous determination of Amaranth and Sunset Yellow by ratio derivative voltammetry. Talanta, v.44, p.105-109, 1997.

NI, Y.; BAI, J.; JIN, L. Multicomponent chemometric determination of colorant mixtures by voltammetry. Anal. Lett., v.30, p.1761-1777, 1997.

PEARSON, D. The chemical analysis of foods. (7.ed.). Edinburgh: Churchill Livingstone, 1976. p.50-83.

POHL, P.; SERGIEL, I. Direct determination of the total concentrations of copper, iron and manganese and their fractionation forms in freshly ripened honeys by means of flame atomic absorption spectrometry. Microchim. Acta, v.168, p.9-15, 2010.

SABEL,C.E.; NEUREUTHER, J.M.; SIEMANN, S. A spectrophotometric method for the determination of zinc, copper and cobalt ions in metalloproteins using Zincon. Anal. Biochem., v.397, p.218-226, 2010.

SHAH, S.S.; PARMAR, R.G. Spectrophotometric determination of $\mathrm{Cu}$ (II) using 2-Hydroxy-4N-buoxy-5-bromo Acetophenone Oxime. Asian J. Chem.. v.22, p.1717-1722, 2010 .

SHARMA, A.K.; SINGH, I. Spectrophotometric trace determination of iron in food, milk, and tea samples using a new Bis-azo dye as analytical reagent. Food Anal. Methods, v.2, p.221-225, 2009.

SUZUKI, S.; SHIRAO, M.; AIZAWA, M.; NAKAZAWA, H.; SASA, K.; SASAGAWA, H. Determination of synthetic food dyes by capillary electrophoresis. J. Chromatogr. A, v.680, p.541-547, 1994.

VIDOTTI, E.C.; ROLLEMBERG, M.C.E. Espectrofotometria derivative: uma estratégia simples para a determinação simultânea de corantes em alimentos. Quim. Nova, v.29, p.230-233, 2006.

WANG T.; GUO, Z. Copper in medicine: homeostasis, chelation therapy and antitumor drug design. Curr. Med. Chem., v.13, p.525-537, 2006.

WHITE, S.L.; RAINBOW, P.S. On the metabolic requirements for copper and zinc in molluscs and crustaceans. Marine Environ. Res., v.16, p.215-229, 1985. 
YANG, L.; ZENG, J.; WANG, X-Y; WU, Z.; CHI, H-T.; OUYANG. L.; ZHANG, J-H.; WANG, J-Y. Simultaneous correction for blood matrix effect on determination of magnesium, copper and lead concentration in blood samples by ICP-MS using CAIS, Spectrosc. Spectral Anal., v.30, p.518-522, 2010.
ZOLLINGER, H. Color chemistry: syntheses, properties and applications of organic dyes and pigments. 2.ed. New York: VCH, 1991. 496 p.

Received for publication on $03^{\text {rd }}$ November 2009. Accepted for publication on $07^{\text {th }}$ July 2010 . 